\title{
Assessment of Bacterial Leaf Blight Incidence and Severity in Rice Growing Areas of Pakistan
}

\author{
Rafia Ahsan ${ }^{1}$, Saif Ullah ${ }^{1}$, Ijaz Yaseen ${ }^{1}$, Faisal Sohail Fateh ${ }^{1}$, Muhammad Fayyaz ${ }^{1}$, Shahzad Asad ${ }^{1}$, Atif \\ Jamal $^{1}$, Muhammad Sufyan ${ }^{2}$ and Muhammad Zakria ${ }^{*}$
}

${ }^{1}$ Crop Diseases Research Institute, National Agricultural Research Center, Islamabad, Pakistan; ${ }^{2}$ Crop Diseases Research Institute, Sunny Bank, Murree, Pakistan.

Abstract | Bacterial Leaf Blight (BLB) is a serious disease of irrigated rice in Pakistan. All famous varieties of Basmati rice are susceptible to bacterial blight. Survey of rice growing areas of Punjab, Sindh and Khyber Pakhtunkhwa (KP) was conducted during the year 2019-20. BLB was prevalent in all the surveyed provinces of Pakistan. In Punjab, high disease prevalence was observed in Gujranwala (55\%), Hafizabad (36\%), Sialkot (29\%) and Narowal (27\%). No disease was observed in Wazirabad, Zafar Wal and Gujrat. The disease incidence in Gujranwala, Sialkot and Narowal was 35\%,50\% and $21 \%$ respectively, and severity ranged from $0-80 \%, 0-70 \%$ and $0-70 \%$ respectively. In KP 3 rice growing areas were surveyed. In Mansehra the disease incidence (37\%) and severity (0-70\%) was lower compared to Swat and lower Dir. In comparison to Punjab and KP, BLB was less prevalent in Sindh. Highest disease prevalence was recorded in Badin (13\%) followed by $10 \%$ in Shikarpur. In total, forty seven diseased leaf samples were collected from the entire surveyed locations. Thirty isolates were confirmed as Xanthomonas oryzae pv. oryzae (Xoo) through PCR and pathogenicity on susceptible host. The results indicate that BLB is continuously present in rice growing areas of Pakistan specially in Basmati area of Punjab for last many years. There is need to introduce resistant Basmati varieties to reduce the inoculum level and yield losses.

Received | November 19, 2020; Accepted | January 12, 2021; Published | August 18, 2021

*Correspondence | Muhammad Zakria, Crop Diseases Research Institute, National Agricultural Research Center, Islamabad, Pakistan; Email: rmzakria@hotmail.com

Citation | Ahsan, R., S. Ullah, I. Yaseen, F.S. Fateh, M. Fayyaz, S. Asad, A. Jamal, M. Sufyan and M. Zakria. 2021. Assessment of bacterial leaf blight incidence and severity in rice growing areas of Pakistan. Pakistan Journal of Agricultural Research, 34(4): 693-699.

DOI | https://dx.doi.org/10.17582/journal.pjar/2021/34.4.693.699

Keywords | Bacterial leaf blight, Xanthomonas oryzae pv. oryzae, Incidence, Severity, Molecular identification

\section{Introduction}

$\mathrm{P}$ akistan is an agricultural country, blessed with favorable temperature and climate for the production of rice. It is imperative to mention that rice being the $3^{\text {rd }}$ most important crop of Pakistan, it is covering over $10 \%$ of total land area for cultivation and contributes about $17 \%$ in the production of cereal grains of the country (Ali et al., 2009; Hussain et al., 2008).

By increase in international travel and trade, there is a threat of introduction of many pathogenic species and pest in the agricultural sector (Graham et al., 2004). A considerable amount of rice crop is lost every year due to the infestation of diseases caused by numerous bacteria, viruses and fungi. Leaf blast, bacterial leaf blight (BLB) and sheath blight are categorized as the three most damaging diseases of cultivated rice. Among these three, most serious and devastating disease of the rice crop in Asian continent is BLB which is caused by the pathogen, Xanthomonas oryzae pv. oryzae (Xoo) (Yang, 2010; Arshad et al., 2017). The disease is very much common in Asia, Australia, 
Latin America and United States. However, it was reported first time in Kyushu, Japan during 1884-85 (Yamanuki et al., 1962).

Bacterial leaf blight early symptoms appear on the leaf blades at tillering stage, starting from lower plant parts and then reaching to above ones. (Goto, 1992; Cha, 1982). In case of severe attack, the disease is clearly visible in vulnerable genotypes receiving nitrogen fertilizer higher dosage. The entire leaf blade area turns pale yellow (Mizukami and Wakimoto, 1969). In most damaging case, yellow to white stripes are seen just inside the margins of the leaf blades, turning yellow and at the end result in mortality of leaf tissues $(\mathrm{Ou}, 1985)$.

During 1985 the yield losses by BLB were reported between 25-35\% in Japan (Ou, 1985). Similarly, high yield losses (24-50\%) were reported in Philippines (Exconde, 1973) and India 12-32\% (ShahJahan, 1992). In Pakistan, it is expanding its area year after year. Almost all famous varieties of Pakistan's Basmati rice are susceptible to this disease. BLB cause yield losses due to decrease in photosynthetic activities of plant. Losses may range from $30-50 \%$ to $100 \%$ in case bacterial infection occurs at tillering stage of crop (Khan et al., 2012).

It has been observed that high speed winds along with rain favor the BLB spread. Sometimes, other mechanical means spread the disease to change it into an epidemic. (Muko et al., 1957; Srivastava, 1972). Some of the scientists reported that genotype of the variety plays important role in susceptibility (Singh et al., 1977) while, others stated that field management $(\mathrm{Ou}, 1985)$ also contribute in the disease development. Therefore, disease estimation at right time and management strategies implemented accordingly let the crop yield to improve within stipulated time.

In Pakistan, BLB disease was first reported in 1977 at Kala Shah Kaku, Rice Research Institute (Mew and Majid, 1977). It was also reported in the paddy rice cultivars, Palmaan, IRRI 6, and Basmati 198 (Ahmad and Majid, 1980). BLB incidence is increasing in Pakistan especially in Kallar belt known for producing high quality Basmati rice with special aroma (Khan et al., 2000). In addition, BLB is increasing in many farmer fields of KP, Punjab and Sindh, 21-26\%, 16$22 \%$ and $11-16 \%$, respectively (Akhtar and Sarwar, 1986). Therefore, present study was planned to check the current status of BLB in major rice growing areas of Pakistan. The data generated by the study is helpful for researchers to assess disease scenario under climate change scenario.

\section{Material and Methods}

\section{Survey and collection of diseased samples}

Major rice growing areas of Punjab, KP and Sindh provinces were surveyed during the year 2019-20. In Punjab province; Sargodha, Hafizabad, Sheikhupura, Sialkot, Narowal, Gujranwala, Wazirabad, Zafarwal and Gujrat districts were surveyed. In KP, Mansehra, Swat and Lower Dir districts were surveyed for the presence and severity of BLB. Shikarpur, Sukkur, Jacobabad, Nawab shah, Tando Muhammad Khan, Badin, Sajawal and Thatta of Sindh province were recorded for BLB incidence and severity.

During the field surveys, positive sampling was done and rice leaves naturally infected with BLB were collected at pre-panicle stage, with appearance of yellow to white water-soaked stripes lesions at the margins of infected leaves (Figure 1D and E). Leaves were sliced into $0.5-1 \mathrm{~cm}$ length from an area where the lesion is still advancing.

Data on disease prevalence, incidence and severity was recorded using following formulas:

Prevalence (\%): Prevalence is on the basis of presence or absence of BLB in the field.

Incidence (\%): Number of diseased plants/Total plants observed x 100

Severity (\%): Severity was recorded by taking the percentage of leaf area infected by BLB using following scale (IRRI, 1996).

$\begin{array}{ll}\text { Disease rating } & \text { Lesion size (\% of leaf length) } \\ 0 & 0 \\ 1 & >1-10 \\ 3 & >11-30 \\ 5 & >31-50 \\ 7 & >51-75 \\ 9 & >76-100\end{array}$

Isolation and purification of Xanthomonas oryzae pv. oryzae

Infected parts of BLB leaves were disinfected in $70 \%$ ethanol for 1 minute. The leaf tissues were rinsed thrice with double distilled water and cut in 
to small pieces with sterilized scissor and dipped in double distilled water in micro centrifuge tube for 1 hour for bacteria to be oozed out (Figure 2A and B). Bacterial suspension in water was streaked on Wakimoto's media and kept in incubator for 5-7 days at $28-30^{\circ} \mathrm{C}$ (Figure $2 \mathrm{C}$ ). Lemon yellow colored single colonies with shiny circular surface were picked and purified on fresh Wakimoto's media plates (Figure $4 \mathrm{~A}$ ). For long-term storage, the purified cultures were preserved at $-20{ }^{\circ} \mathrm{C}$ and $-80^{\circ} \mathrm{C}$ in $1: 1$ of $50 \%$ glycerol and Nutrient broth.

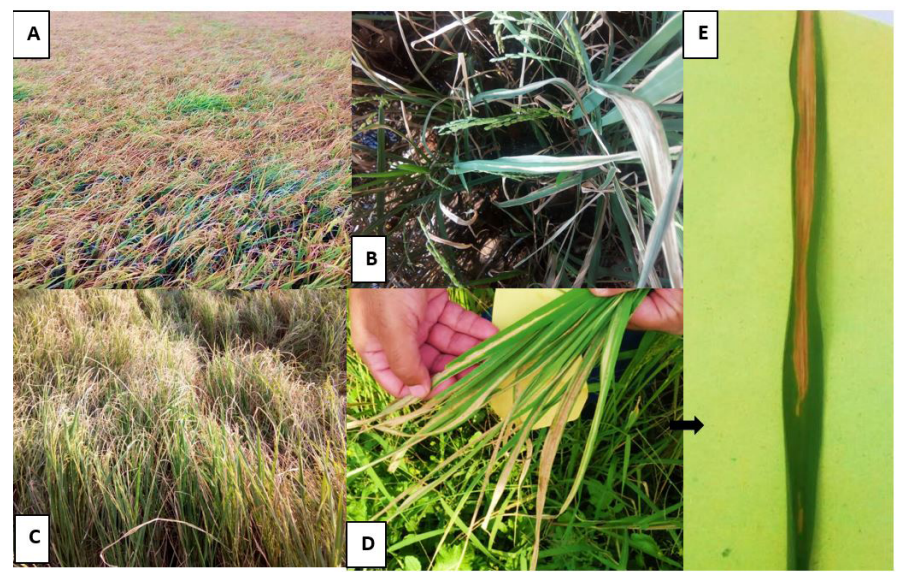

Figure 1: $(A),(B)$ and $(C)$ Rice fields infected with BLB in $K P K$, Sindh and Punjab province respectively. (D), (E); The leaves showedyellowish lesions/stripes at the margins and along midrib with wavy edges.

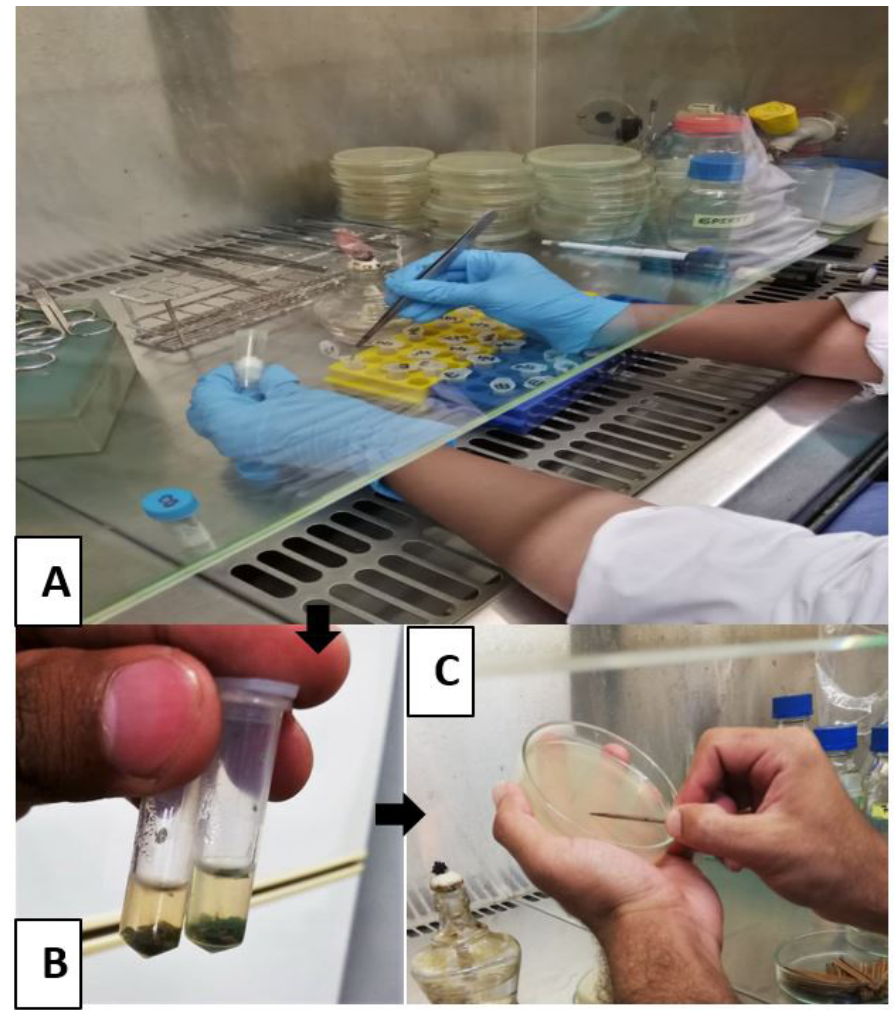

Figure 2: (A); Surface sterilization of BLB leaves. (B); Leaves cut into small pieces with sterilized scissors in a tube containing $d d_{2} \mathrm{H}_{2} \mathrm{O}$ and the bacteria were allowed to be ooze out. (C); Streaking of bacterial suspension with wooden stick on Wakimoto's media.
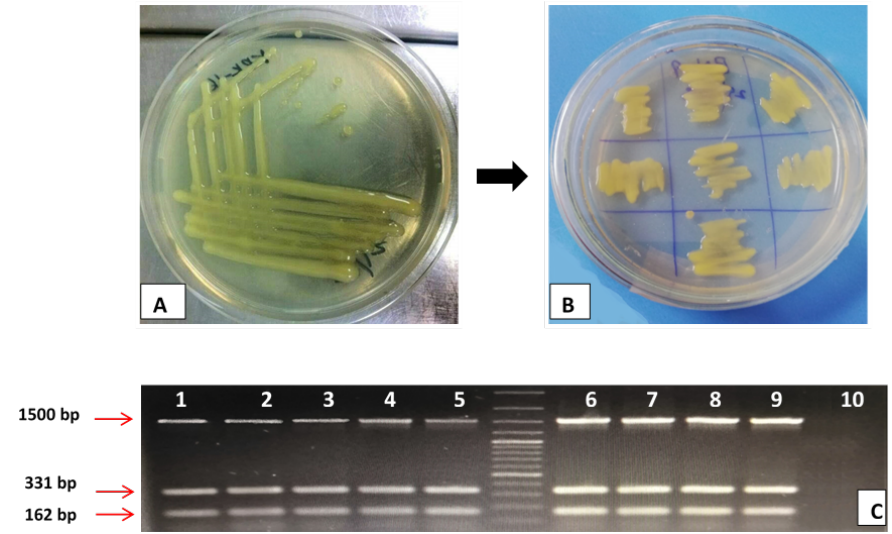

Figure 3: (A) Isolation of Xoo on Wakimoto's media; Yellow, smooth, shiny circular Xoo colonies after 3-5 days of incubation at $28-30^{\circ} \mathrm{C}$. (B); Single colonies sub cultured on fresh plates for colony PCR. (C), Agarose gel electrophoresis: Multiplex colony PCR of samples from $K P(1-4)$ and Punjab (5-8) showing band size of 1500bp, 331bp and $162 b p$ with $16 \operatorname{SrDNA}, X_{03756}(F, R)$ and $X 003866(F, R)$ primers respectively. 100bp+Ladder between line 5 and 6, 9 line is PXO-99 (positive control), 10 is Negative control.
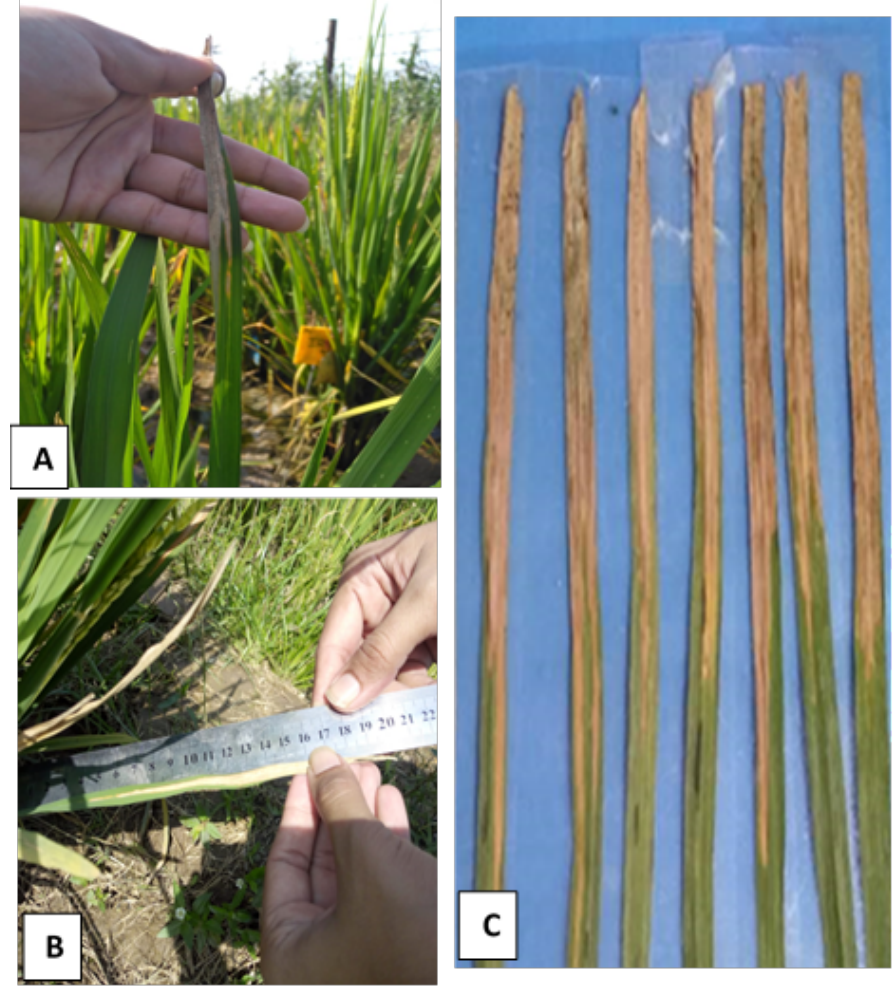

Figure 4: $(A, B$ and $C)$; Typical symptoms of $B L B$ observed on Basmati leaves after 21 days of inoculation.

\section{Molecular identification of Xoo}

Multiplex colony PCR (Vera-Cruz et al., 2017) was done, using primers, Xo3756 (331bp), Xoo80 (162bp) and Xoc3866 (691bp); for identification of Xanthomonas oryzae, Xanthomonas oryzae pv. oryzae and Xanthomonas oryzae pv. oryzicola respectively (Figure 3C).

\section{Pathogenicity test}

The pathogenicity of $X_{00}$ isolates were confirmed 
under field conditions, using leaf clip method (Kauffman et al., 1973). Forty-five days old seedlings of susceptible rice cultivar (Super Basmati) were used for inoculation. The leaves were clip-inoculated at $1-2 \mathrm{~cm}$ from tip with sterile scissors that had been dipped in the bacterial suspension containing $10^{8}$ $\mathrm{CFU} / \mathrm{ml}$ (Figure 4A).

The lesion length was measured after 14 days of inoculation as follows: $0-5 \mathrm{~cm}=\mathrm{R}, 6-10 \mathrm{~cm}=\mathrm{MR}, 11-$ $15 \mathrm{~cm}=\mathrm{MS}$, above $15 \mathrm{~cm}=\mathrm{S}$ (IRRI, 1996).

\section{Results and Discussion}

\section{Status of bacterial blight}

$\mathrm{BLB}$ was prevalent in all the surveyed provinces of Pakistan (Figure 1A, B and C). In Punjab, high disease prevalence was observed in Gujranwala (55\%), Hafizabad (36\%), Sialkot (29\%) and Narowal (27\%). No disease was observed in Wazirabad, Zafar Wal and Gujrat. The disease incidence in Gujranwala, Sialkot and Narowal was 35\%,21\% and 50\%, respectively and severity ranges from 0-9, 0-7 and 0-7, respectively. In KP 3 rice growing areas were surveyed. The disease prevalence was high in Swat (20\%) and Mansehra (12\%). In Mansehra the disease incidence (37\%) and severity (0-7) was high compared to Swat and lower Dir. In Sindh disease was less prevalent. Highest disease prevalence was recorded in Badin (13\%) followed by $10 \%$ in Shikarpur (Table 1).

\section{Isolation and identification of Xoo}

Forty-seven diseased leaf samples were collected from the entire surveyed locations and processed for isolation and further studies. Yellowish colonies of bacteria were consistently isolated and purified. (Figure $3 \mathrm{~A}$ and $\mathrm{B}$ ). Thirty isolates have been confirmed through PCR which yielded a band size of $162 \mathrm{bp}$ on gel (Figure 3C).

\section{Assessment of pathogenicity}

All positive isolates (confirmed by PCR) were inoculated on susceptible rice cultivar (Super Basmati) for confirmation of their pathogenicity. All isolates showed typical symptoms with white to yellows stripes from top to bottom of leaves with wavy margins after 21 days of inoculation (Figure 4A, $B$ and $C)$.

BLB of rice is known to cause severe losses when comes in epidemic form. In the current study BLB was prevalent in all the 3 surveyed provinces. In Punjab and KP the disease incidence and severity were high compared to Sindh. Similar pattern of high incidence and severity has been reported previously from Punjab (Sialkot, Narowal, Hafizabad, Gujranwala and Sheikhupura) and KP (Lower Dir, Swat and Mansehra) by different researchers. However, in Sindh generally low disease incidence and severity was reported except for Badin where incidence up to 40\% have been reported (Akhtar and Sarwar, 1986; Akhtar et al., 2003; Rafi et al., 2013). The severity of the diseases varied among different rice growing zones because of the crop age. It has been found that some of the varieties show severe symptoms during vegetative stage and others show aggressiveness near maturity (Philip and Devadth, 1980). Similar results were also reported in Korea by Cha et al., 1982. who observed maximum incidence in young age plants.

Table 1: Status of bacterial leaf blight of rice in Punjab, KP and Sindh during 2019-20 season.

\begin{tabular}{|c|c|c|c|c|}
\hline Province & Location & $\begin{array}{l}\text { Preva- } \\
\text { lence (\%) }\end{array}$ & $\begin{array}{l}\text { Incidence } \\
\text { (\%) }\end{array}$ & $\begin{array}{l}\text { Severity } \\
\text { scale }\end{array}$ \\
\hline \multirow[t]{9}{*}{ Punjab } & Sargodha & 05 & 10 & $0-5$ \\
\hline & Sialkot & 29 & 21 & $0-7$ \\
\hline & Narowal & 27 & 50 & $0-7$ \\
\hline & Gujranwala & 55 & 35 & $0-9$ \\
\hline & Sheikhupura & 08 & 2.5 & $0-3$ \\
\hline & Hafizabad & 36 & 20 & $0-7$ \\
\hline & Wazirabad & 0 & 0 & 0 \\
\hline & Zafar Wal & 0 & 0 & 0 \\
\hline & Gujrat & 0 & 0 & 0 \\
\hline \multirow{3}{*}{$\begin{array}{l}\text { Khyber Pa- } \\
\text { khtunkhwa }\end{array}$} & Mansehra & 12 & 37 & $0-7$ \\
\hline & Swat & 20 & 30 & $0-5$ \\
\hline & Lower Dir & 08 & 03 & $0-3$ \\
\hline \multirow[t]{9}{*}{ Sindh } & Qambar & 03 & 2.5 & $0-1$ \\
\hline & Shikarpur & 10 & 4 & $0-1$ \\
\hline & Badin & 13 & 4 & $0-1$ \\
\hline & Larkana & 0 & 0 & 0 \\
\hline & Jacobabad & 0 & 0 & 0 \\
\hline & $\begin{array}{l}\text { Tando Muham- } \\
\text { mad Khan }\end{array}$ & 0 & 0 & 0 \\
\hline & Sajawal & 0 & 0 & 0 \\
\hline & Thatta & 0 & 0 & 0 \\
\hline & Sukkur & 0 & 0 & 0 \\
\hline
\end{tabular}

The diseased samples collected were processed for isolation of $X 00$. In most of the previous studies from Pakistan biochemical, morphological or some other 
primers have been used to identify Xoo. In this study multiplex PCR recommended by IRRI, Philippines was used to identify the suspected Xoo isolates (Vera Cruz et al., 2017). A number of primers for Xoo have been reported in the literature (Niño-Liu et al., 2006; Sakthivel et al., 2001; Lang et al., 2010). Multiplex PCR was used in this study as it simultaneously detects $X 00$ and differentiate its close relative, Xanthomonas oryzae pv. oryzicola (Xoc). Thirty isolates were confirmed as $X 00$ and all isolates produced blight symptoms on rice with no significant differences in severity on rice plants.

The previous and current studies showed that BLB is consistently present in all the major rice growing districts of Punjab from last 20-25 years. This is due to the fact that mostly old basmati varieties such as super basmati and others which lack effective resistance genes against BLB are being cultivated on major area. In KP susceptible varieties Bas-385, Begumie, JP-5 and Fakhr-e-Malakand, Swat-1 and Swat-11 are still being cultivated. The infected seed of these cultivars is the reason of introduction of the pathogen directly into the rice nurseries (Akhtar and Zakria, 2003; Akhtar et al., 2003; Naqvi, 2019). In Sindh mostly imported hybrids are being cultivated which generally have better resistance against BLB and this might be the reason of low incidence. To date about 45 bacterial leaf blight resistance genes $(R)$ have been reported (Busungu et al., 2016; Liang et al., 2017). However, pathogen is changing continuously and new races of $X 00$ are emerging which break down the resistance provided by $\mathrm{R}$ genes (Lore et al., 2011). So, it is necessary to breed and introduce varieties with effective resistance against BLB which will help in reducing the yield losses and also the inoculum pressure in the field.

BLB is highly dependent on favorable environmental conditions (high temperature and rainfall) for its establishment and also depend on mechanical means for its spread (Yang, 2010; Goto et al., 1955). Heavy rainfalls in the month of August and September have effect on the intensity of BLB in the field. The strains isolated during the reporting period will be subjected to pathotyping and identification of resistance sources. The information generated will help in understanding the race spectrum of Pakistani Xoo isolates and will also give the information that which BLB resistant genes are stable/broke down against these races.

\section{Novelty Statement}

In this manuscript Bacterial blight of rice diseases status during 2019-20 is reported and the confirmation of its pathogen i.e. Xanthomonas oryzae pv. oryzae was done on molecular basis.

\section{Author's Contribution}

\section{Rafia Ahsan, Saif Ullah, Ijaz yaseen, Faisal Sohail Fateh and Muhammad Sufyan: Conducted the} experiments.

Muhammad Fayyaz and Atif Jamal: Performed data analysis.

Shahzad Asad: Wrote manuscript.

Muhammad Zakria: Conceived the idea and wrote manuscript.

\section{Conflict of interest}

The authors have declared no conflict of interest.

\section{References}

Ahmad, W. and A. Majid. 1980. Incidence of Bacterial Blight of rice in the Punjab (Pakistan). IRRN. 5:5.

Akhtar, M.A. and M. Sarwar. 1986. Major rice diseases and their control. In: Progressive Farming. Nat.

Akhtar, M.A. and M. Zakria. 2003. Incidence of bacterial leaf blight of rice in Pakistan during 2002. Pak. J. Bot., (Pakistan), 35(5): 993-997.

Akhtar, M.A., M.H. Bhatti and M. Aslam. 1997. Anti-bacterial activity of plant diffuse at against Xanthomonas campestris pv. citri. Int. J. Pest Manage., 43: 149-153. https://doi. org/10.1080/096708797228861

Akhtar, M.A., Zakria and F.M. Abbasi. 2003. Inoculum buildup of bacterial leaf blight of rice in rice-wheat cropping area of Punjab in relation to zero tillage. Asian J. Plant Sci., 2: 548-550. https://doi.org/10.3923/ajps.2003.548.550

Ali, A., M.H. Khan, R. Bano, H. Rashid, N.I. Raja and Z. Chaudhry. 2009. Screening of Pakistani rice (Oryza sativa) cultivars against Xanthomonas oryzae pv oryzae. Pak. J. Bot., 41(5): 2595-2604. Arshad, H.M.I., K. Saleem, J.A. Khan, M. Rashid, M. Atiq, S.S. Alam and S.T. Sahi. 2017. Pathogenic diversity of Xanthomonas oryzae pv. oryzae isolates collected from Punjab Province of Pakistan. Eur. J. Plant Pathol., 147(3): 639- 
651.

https://doi.org/10.1007/s10658-016$1032-5$

Busungu, C., S. Taura, J.I. Sakagami and K. Ichitani. 2016. Identification and linkage analysis of a new rice bacterial leaf blight resistance gene from XM14, a mutant line from IR24. Breed. Sci., 66: 636-645. https://doi.org/10.1270/ jsbbs.16062

Cha, K.H., Y.S. Kim, H.I. Kim, D.K. Lee and M.S. Kim. 1982. Effects of application levels of fertilizer on the susceptibility to bacterial leaf blight, yield and quality of grains in nineteen rice cultivars in Jeonnam Region. Korean J. Plant Proct., 21: 216-221.

Exconde, O.R., 1973. Yield losses due to bacterial leaf blight of nee. Philip. Agric., 57: 128-140.

Goto, K., Y. Inoue, R. Fukatsu and K. Ohata. 1955. Field outbreak and fluctuation of severity of Bacterial leaf blight of rice plant. Bull. TokaiKinki Agric. Exp. Sta., 2: 53-68.

Goto, M., 1992. Fundamentals of bacterial plant pathology. San Diego. Calif. USA: Acad. Press. pp. 342. https://doi.org/10.1016/B978-0-12293465-0.50009-1

Graham, J.H., T.R. Gottwald, J. Cubero and D.S. Achor. 2004. Xanthomonas axonopodis pv. citri: factors affecting successful eradication of citrus canker. Mol. Plant Pathol., 5(1): 1-15. https:// doi.org/10.1046/j.1364-3703.2004.00197.x

Hussain, A.H., N.U.R.K. Khattak and A.Q.K. Khan. 2008. Costs benefit analysis of different rice varieties in district Swat. Sarhad J. Agric., 24(4): 745-748.

IRRI, 1996. International Rice Research Institute, 1996. Standard evaluation system for rice. International Rice Testing Program PO Box 933, Manila, Philippines.

Kauffman, H.E., A.P.K. Reddy, S.P.Y. Hsieh and S.D. Merca. 1973. An improved technique for evaluating resistance of rice varieties to Xanthomonas oryzae. Plant Dis. Rep., 57: 537541.

Khan, J.A., F.F. Jamil and M.A. Gill. 2000. Screening of rice varieties/ lines against Bakanae and Bacterial blight (BB). Pak. J. Phytopathol., 12(1): 6-11.

Khan, J.A., R. Siddiq, H.M.I. Arshad, H.S. Anwar, K. Saleem and F.F. Jamil. 2012. Chemical control of Bacterial blight of rice caused by Xanthomonas oryzae pv. oryzae. Pak. J. Phytopathol., 24(2): 97-100.
Lang, J.M., J.P. Hamilton, M.G.Q. Diaz, M.A. Van Sluys, M.R.G. Burgos, C.M. Vera Cruz, C.R. Buell, N.A. Tisseratamd and J.E. Leach. 2010. Genomics-based diagnostic marker development for Xanthomonas oryzae pv. oryzae and $X$. oryzae pv. oryzicola. Plant Dis., 94: 311319. https://doi.org/10.1094/PDIS-94-3-0311

Liang, L.Q., C.Y. Wang and L.X. Zeng. 2017. The rice cultivar Baixiangz han harbors a recessive gene $x a 42(t)$ determining resistance against Xanthomonas oryzae pv. oryzae. Plant Breed, 136: 603-609. https://doi.org/10.1111/ pbr.12493

Lore, J.S., Y. Vikal, M.S. Hunjan, R.K. Goel, T.S. Bharaj and G.L. Raina. 2011. Genotypic and pathotypic diversity of Xanthomonas oryzae pv. oryzae, the Cause of Bacterial Blight of Rice in Punjab State of India.J.Phytopathol., 159: 479-487. https://doi.org/10.1111/j.14390434.2011.01789.x

Mew, T.W. and A. Majid. 1977. Bacterial blight of rice in Pakistan. Int. Rice. Res. Newsl., 2: 5.

Mizukami,T.and S.Wakimoto.1969.Epidemiology and control of bacterial leaf blight of rice. Ann. Rev. Phytopathol., 7: 51-72. https://doi. org/10.1146/annurev.py.07.090169.000411

Muco, H., T. Kusaba, M. Watanabe and H. Tabei. 1957. Several factors related to the occurrence of bacterial leaf blight disease of rice. Proc. Kanto-Tosan, P1. Proct. Soc., 4: 7-8.

Naqvi, S.A.H., 2019. Bacterial leaf blight of rice: An overview of epidemiology and management with special reference to Indian sub-continent. Pak. J. Agric. Res., 32(2): 359. https://doi. org/10.17582/journal.pjar/2019/32.2.359.380

Niño-Liu, D.O., P.C. Ronald and A.J. Bogdanove. 2006. Xanthomonas oryzae pathovars: Model pathogens of a model crop. Mol. Plant Pathol., 7(5): 303-324. https://doi.org/10.1111/j.13643703.2006.00344.x

Ou,S.H.,1985. Rice diseases. Kew: Commonwealth Mycological Institute.

Philip, R. and S. Devadath. 1980. Effect of inoculum concentration of wild and mutant colony types of Xanthomonas oryzae on the disease development in rice. Oryza, 17: 38-41.

Rafi, A., A. Hameed, M.A. Akhtar, S.M.A. Shah, M.Junaid, M. Shahid and S.F. Shah.2013. Field based assessment of rice bacterial leaf blight in major rice growing zones of Pakistan. Sarhad J. Agric., 29(3): 415-422. 
Sakthivel, N., C. Mortensen and S. Mathur. 2001. Detection of Xanthomonas oryzae pv. oryzae in artificially inoculated and naturally infected rice seeds and plants by molecular techniques. Appl. Microbiol. Biotechnol., 56: 435-441. https:// doi.org/10.1007/s002530100641

Shajahan, A.K.M., 1992. Development of technologies and their transfer to farmers in Bangladesh. Crop Sci. Soc. Bangladesh, pp. 34.

Singh, G.P., M.K. Srivastava, R.V. Singh and R.M. Singh. 1977. Variation in quantitative and qualitative losses caused by bacterial blight in different rice varieties. Indian Phytopathol., 3: 180-185.

Srivastava, D.N., 1972. Bacterial blight of rice. Indian Phytopathol., 25: 1-16.

Vera Cruz, C.M., B. Cottyn, M.H. Nguyen, J.
Lang, V. Verdier, T.W. Mew and J.E. Leach. 2017. Detection of Xanthomonas oryzae pv. oryzae and Xanthomonas oryzae pv. oryzicola in rice seeds. Chapter 8 in APS manual on detection of plant pathogenic bacteria in seed and planting material. APS Press. https://doi. org/10.1094/9780890545416.008

Yamanuki, S., K. Nakamura, M. Kayano, T. Narita and T. Iwata. 1962. First occurrence of bacterial leaf blight of rice in Hokkaido. Ann. Phytopathol., 27: 264.

Yang, C.M., 2010. Assessment of the severity of bacterial leaf blight in rice using canopy hyperspectral reflectance. Precis. Agric., 11(1): 61-81. https://doi.org/10.1007/s11119-009$9122-4$ 